\title{
Transforming Tertiary EFL Learners' Meta-Linguistic Knowledge and Practices: A Longitudinal Case Study
}

Xiaodong Zhang

Beijing Foreign Studies University, School of English and International Studies

\section{Abstract}

This study reports on how the explicit teaching of language use as meaning-making in context (i.e., language use as a dynamic interaction between context, meaning, and linguistic features) impacted tertiary English as a foreign language (EFL) learners' meta-linguistic knowledge of the English language, as well as their language learning practices. Based on a qualitative analysis of interviews, conversations, and written samples gathered from one college-level EFL student over one academic year, the study shows that the EFL student's appropriation of a new meta-linguistic perspective of language use as meaning-making in context - which differed from her previous understandings of language use as de-contextualized sentential accuracy - was a process of interacting with diverse factors. These factors included her passion for challenging herself and constructing her professional identity. Additionally, over the year, the EFL student also adopted corresponding language literacy practices, which resonates with the endorsed language literacy valued by authentic English language communities.

Key words: English as a foreign language; language learners; meaning-making; systemic functional linguistics; transition.

\section{Introduction}

In English as a foreign language (EFL) contexts, many language learners from the elementary level to the tertiary level are exposed to the learning and instruction of grammatical rules when constructing/deconstructing sentences in writing and when reading texts (Aunurrahman, Hamied, \& Emilia, 2017; Fu \& Matoush, 2012; Tran, 2007; 
Yasuda, 2015). In this scenario, EFL learners gain limited linguistic knowledge about effective language learning, and thus fail to meet the academic expectations of authentic English communities where endorsed language literacy (e.g., reading and writing) involves language learners' knowledge of complex relationships between language resources and context as well as English language culture (Moore \& Schleppegrell, 2014; Schleppegrell, Achugar, \& Oteíza 2004). In addition, many college students who already have adequate knowledge of maintaining structural accuracy are anxious to challenge themselves and construct their identity as advanced English learners (Tran, 2007; Zhang, 2017). However, as a result of continually being taught grammatical rules, they come to doubt themselves and become increasingly unmotivated to continue their studies (Harklau, 2000; Humphrey \& Macnaught, 2016; Hyland, 2002; Ushioda, 2011). In other words, there is an imperative need to refresh college EFL students' existing meta-linguistic knowledge (i.e., the theoretical perspective of language that students rely on to understand and learn language) (Negretti, 2012) and enhance their language performance as English language learners, as endorsed by authentic academic English communities, closing "the achievement gap between speakers of dominant and nondominant varieties of English” (Humphrey \& Macnaught, 2016, p. 21).

\section{Theoretical Framework}

\section{Systemic Functional Linguistics: Complementing Students' Understanding of Language}

Systemic functional linguistics (SFL) (Halliday, 1994; Martin \& White, 2005; Rose \& Martin, 2012) highlights language users' meta-linguistic knowledge from a meaningmaking perspective. That is, SFL emphasizes the necessity of language users' metalinguistic knowledge about language as meaningful units emerging out of interactions between context, meaning, and linguistic features (grammar and vocabulary), along with its explicit framework explaining this mechanism.

In particular, SFL's framework includes the constructs of the context of situation (i.e., register), three meta-meanings, lexico-grammar, and the context of culture (i.e., genre). Context of situation (i.e., register) describes information about the context of the immediate situation related to a communication activity and includes three variables: field (i.e., the main topic of language activities), tenor (i.e., the interpersonal relationship involved in language activities), and mode (i.e., the channel of language activities that are delivered). Anchored by the three variables, language as a meaning unit presents itself in three facets: (1) ideational meaning (i.e., semantic embodiment of field, focusing on language users' knowledge about a language event); (2) interpersonal meaning (i.e., semantic embodiment of tenor, focusing on language users' interactional pattern and evaluative stance toward language events); and (3) textual meaning (i.e., semantic representation of mode, with a focus on the information flow of language events). In the process of constructing the three meanings, SFL further provides lexicon and grammar (more nuanced categories), which explain the three meta-meanings of language events. 
In deconstructing/constructing ideational meaning, major lexico-grammatical codes include participant (noun phrases), process (verb), and circumstance (prepositional phrases). Similarly, interpersonal meaning is realized through codes such as subject (nouns) and predicate, as well as residue (adverbial phrases or prepositional phrases). The order of subject and predicate shows an interactional pattern (e.g., subject - predicate = statement vs. predicate - subject $=$ question). Within the interpersonal dimension, there is also an appraisal system coding language users' evaluative stance; the codes include attitude (words denoting or connoting attitude), graduation (words denoting or connoting the degree of lexical meaning), and engagement (words denoting or connoting the source or the certainty of information). Textual meaning is constructed out of codes such as theme (the starting point of a sentence that at least includes an element carrying substantial content) or cohesive ties, which include grammatical codes (e.g., conjunctions) and lexical codes (e.g., synonyms or antonyms). The meaning realized through lexico-grammar in the context of situation is also organized into certain stages to achieve a specific social purpose (e.g., to argue or explain) in response to the context of culture/genre (i.e., the cultural practices on achieving a certain purpose in a certain language community).

\section{Literature Review}

Because SFL tenets successfully echo curricular requirements focusing on training language learners to understand meaningful content and appropriate language features in dominant English speaking countries, such as the United States or Australia, SFLbased English language teaching in these countries has become widely implemented (e.g., Chen \& Myhill, 2016; Dreyfus, Humphrey, Mahboob, \& Martin, 2016; Fang \& Schleppegrell, 2010; Gebhard, Chen, \& Britton, 2014). As Schleppegrell et al. (2004) noted, "this [SFL] is a solid foundation on which to incorporate an explicit focus on how language is used in different subject areas to construe particular kinds of meanings." For instance, in Gebhard et al.s (2014) study, elementary English as a second language (ESL) students, whose first language was Spanish, became proficient learners in both reading and writing English texts, as illustrated by their adroit maneuvers in decoding or coding language as meaning-making resources involving lexical choices in context (such as students' exemplification of knowledge and practice of specific verbs in writing and reading scientific explanations). In an Australian urban secondary school, Humphrey and Macnaught's (2016) 18-month longitudinal study of ESL students who had limited meta-linguistic knowledge and SFL-based knowledge, became better at performing reading and writing through SFL-based meta-linguistic discussions with their teachers, which was then mapped to their own reading and writing, such as their knowledge of concession (e.g., although) and use of engagement (e.g., possibly). In contrast to ESL contexts, studies in EFL contexts are still limited. Aunurrahman et al. (2017) showed that Indonesian college students' writing improved through SFL-based 
teaching, as exemplified by their good control of linguistic features of three types of writing (exposition, discussion, and response to literary works), such as students' use of theme-rheme patterns to construe fluent texts as required by different genres.

As seen from the above mentioned studies, abundant literature in ESL contexts has illustrated the power of SFL in developing language learners' meta-linguistic knowledge and assisting them in achieving success in English literacy (e.g., writing and reading). In contrast, studies in EFL contexts, especially at the tertiary level, are still limited, as most curriculum requirements still focus on structural accuracy, or in some cases teacher education is still not effectively enacted (Tran, 2007; Zhang, 2017). Even among the limited studies on teaching EFL at the tertiary level (e.g., Aunurrahman et al., 2017; Yasuda, 2015), these studies have focused more on linguistic feature changes in students' writing, separating students' meta-linguistic knowledge from their actual language practices. As such, there is still a lack of insight into how changes to tertiary EFL students' meta-linguistic knowledge influence their language practices, although "what learners will develop as cognitive resources for future activities is influenced by what they have become aware of"(Chen \& Myhill, 2016, p. 101). Given the research gap in the context of EFL as well as the imperative need to prepare tertiary EFL students to meet the literacy challenges of authentic English language communities, this paper presents a longitudinal case study of one college EFL student's experiences with SFL. The study was guided by the following two interrelated research questions:

(1) How does the EFL student respond to an SFL-based curriculum aimed at developing students' meta-linguistic knowledge about the English language?

(2) How does the EFL student's SFL-based meta-linguistic knowledge impact her English language practices, if at all?

\section{Methodology}

\section{Participants and Research Context}

The EFL student profiled in this research, Lee, was included in this project as a secondyear English major student. Lee was interested in learning English and had initially been happy about being an English major student at one of the best universities in China. However, in her second year of studies she started feeling as though she was in a rut: she was lost about how to pursue learning as she was still receiving language education similar to what she had received in high school (i.e., learning vocabulary or focusing on structural accuracy) (cf., Zhang, 2017). She said she could learn this by herself and really wanted to become an advanced learner who could communicate effectively with native English speakers (Ushioda, 2011; Tran, 2007). In other words, Lee was faced with an imperative need to improve her knowledge of English and construct her professional identity as an English major student.

In the spring of 2016, Lee started taking an academic writing course with the researcher of this project. In this class, SFL was new to all students, and its teaching was mediated by the author of the paper, who aimed to connect the core content of SFL with 
students' previous learning of language and refresh their meta-linguistic knowledge. While there are many terms in SFL, minimal terminology was used during class and many terms were translated into the students' first language when necessary. Over the whole semester, the main constructs of SFL were taught: genre, register, three metafunctions, lexico-grammar, as well as the interconnections between these constructs. The main linguistic labels (e.g., theme, cohesive ties, participant, and graduation) that are used to code/decode the three meta-meanings were also taught. Concurrently with the course, Lee also enthusiastically joined a workshop conducted by the author of this paper, which further improved her knowledge of SFL. In the second semester, though she was no longer taking the writing course, Lee still enthusiastically continued her learning of SFL and its application to a wide scope of genres. Over the academic year, along with her efforts to appropriate SFL-based meta-linguistic knowledge, Lee used SFL to analyze a diverse genre of texts, from argumentation and story, to news report. Because of this, she was selected as one of the most suitable participants for this project.

\section{Data Collection and Analysis}

Data was collected monthly over the academic year, excluding the winter vacation. In particular, in addition to interviews, the researcher's conversations with Lee were also recorded, in which she discussed her ongoing understanding of English literacy in relation to the SFL-based perspective. Conversations and interviews occurred primarily in the student's first language (i.e., Chinese). Additionally, Lee's English writing was collected over the year, including her written analyses of multi-genre texts (in the English language), such as her analyses of the linguistic features of news reports, literature, argumentative texts, spoken language, and her written reflections on cross-linguistic differences between English and her first language. Data analysis was mainly conducted qualitatively in the original language collected (Creswell \& Poth, 2017). Lee's interviews and conversations were transcribed and read multiple times before categories were identified. Relevant categories were then combined to identify themes across the chain of data sets. Lee's writing and written analysis were collected and analyzed through discourse analysis so as to locate her SFL-based meta-linguistic knowledge (Christie \& Martin, 2009). In addition, field notes taken over the academic year were also examined for the purpose of facilitating data analysis.

\section{Results}

As a result of one year of exposure to mediated learning of SFL and related practices, Lee gained SFL-based meta-linguistic knowledge that complemented her previous knowledge of de-contextualized grammar. The process of her meta-linguistic knowledge development was an interaction between her disappointment in herself as a college English major student with limited knowledge of language and her motivation to align herself with native English literacy communities. In particular, the following themes were selected to illustrate the findings in regard to the two research questions. 


\section{Lee's Embracement of a New Language Theory Due to Self-Awareness of Own Limited Knowledge}

Lee's meta-linguistic knowledge had been constrained to grammatical rules of sentences or acquisition of new vocabulary in the English language, with particular focus being given to maintaining structural accuracy. However, Lee's experience with the limited power of her existing linguistic repertoire in tackling an advanced level of English literacy (e.g., reading) led her to accumulate new and effective meta-linguistic knowledge. As Lee said,

Before I came to college, all my English teachers always emphasized learning structural rules or told us to memorize advanced vocabulary. . At university, many other teachers [during my first year] still had similar practices... I felt that was boring and I already had really extensive knowledge of it. . I could just learn everything by myself; why should I go to college? ... I really need new teaching practices. [Interview excerpt 1]

In other words, as a student who already had good knowledge of structural rules and awareness of memorizing vocabulary, her transition to college led her to expect new or more effective ways of understanding the English language. However, during her first year, she was still primarily taught structural grammar or vocabulary accumulation. As a result, Lee was disappointed with existing teaching practices and ready to embrace a new perspective on the English language.

\section{Passion for a New Perspective on Language with a View of Constructing Own Professional Identity}

As an English major student, Lee was confident in terms of her knowledge of grammatical rules. Yet, she was also anxious about achieving her goal of further improving her English, by adding to her existing knowledge to construct her professional identity, as illustrated in the following interview excerpt:

I am still confident as an English major student. They [non-English major students] may read well and also know grammar and know a lot of words... [But] they do not speak well in terms of pronunciation.... But I am also worried... I feel that is the only thing differentiating me from them... I always think about how to enhance my knowledge of English. Even in speaking, I might also have issues with content, although my pronunciation is good. I do not want to talk to my friends or my future students just about grammar or vocabulary. I really want to be like native English speakers or users. [Interview excerpt 2]

As can be seen from this interview excerpt, Lee was confident about being an English major student, and her confidence was based on her ability to articulate English phonetically. Yet, she was not blinded by her confidence. Instead, she was actively reflecting upon her identity as an English major student and was eager to construct it in a professional way that could ultimately lead to her integration with authentic English academic communities. 


\section{Initial Challenges with Understanding SFL}

While Lee was open to appropriating a new theory, she struggled with understanding the theory in and out of class. However, her difficulty with this new theory was tempered by the instructor's mediated teaching and her self-agency. As Lee noted,

There was a time I had difficulty understanding the theory. There are lots of terms. .. and understanding a theory completely is not a one-year thing, and I have other coursework to deal with. . But as an English major student, I have to challenge myself. Fortunately, you [the researcher] also taught... SFL... in and out of the classroom in a really accessible way... I am sure I have not completely understood the theory, but I know the main components. [Interview excerpt 3]

As shown in the interview excerpts, SFL as a theory itself was challenging for Lee, who had no experience with other similar language theories. Unlike learning grammatical rules for sentences, the approach she had been taught from middle school to high school (i.e., six years), this was the first time she experienced a relatively complex theory within a one-year span. Yet, her determination to become an accomplished English major student stimulated her ambitions in the process of learning. Also, teacher's mediation based on plain language (student's first language) added to her confidence in and out of the classroom.

\section{Lee's Understanding of Language as a Meaning-Making Resource}

Over time, through in-and-out-of-class exposure to SFL, Lee gradually went beyond the limits of her previous knowledge of the English language and gained a new conceptualization of language use as a dynamic interaction between context, language, and grammar/lexicon. One recurrent theme that occurred when Lee was interviewed about the formation of her new meta-linguistic knowledge is shown as follows:

Of course, we have to maintain structural accuracy in written language. But context is important to our language use... We cannot speak as we want... We cannot write what we want... and when we read, we cannot just use our own intuition to decode meaning.... It is the case that language users have to know using language is about meaning. .. and the meaning that is achieved through linguistic choices must be accepted by native English communities. . the constructs. . . genre, register, three meanings, and their relationship with vocabulary and grammar are all important to us as language learners. [Interview excerpt 4]

As shown in this recurrent theme that occurred during her one-year interaction with the researcher, Lee obviously was able to re-conceptualize language beyond attending to the mechanical accuracy of sentences or vocabulary accumulation. That is, for Lee, English learning (e.g., speaking, writing, and reading) became related to language users' proficient control of linguistic features (vocabulary and grammar) in achieving contextually appropriate meanings through different channels of language communication. 


\section{Lee's Enhanced Understanding of SFL-Based Meta-Linguistic Concepts as a Result of Reflection on the Personal Knowledge Repertoire}

As an English language learner, Lee did not just passively absorb the newly instructed content on SFL. Instead, her acquiring of SFL-based knowledge was accompanied by her reflection on the role of SFL-based knowledge in actual language literacy. As Lee said,

Especially in reading, sometimes our teachers just relied on their feelings to interpret text meaning. . . when teaching a text my teacher once said the moaning cow indicates a certain meaning. . . However, SFL gives us a lot of categories I can rely on, such as the appraisal system; I can use it to show authors' evaluative stance or attitude... It [SFL] is more convincing. . . I also thought about meaning-making in the Chinese language and it [SFL-based constructs] helps me ascertain the appropriateness of SFL theory. [Interview excerpt 5]

In other words, while Lee was open to a new theory and felt the explanatory power of SFL as a language learning theory, she also strove to reflect upon the SFL-based knowledge she was receiving. By connecting her previous learning experiences in reading classrooms with her current knowledge (e.g., appraisal system) available to her, Lee realized the benefit of SFL in providing categories to more objectively analyze texts instead of relying on readers' intuition or unprincipled analysis. This helped her trust and appropriate SFL-based meta-linguistic language knowledge. In addition, by tentatively connecting SFL-based knowledge with her first language learning theory, Lee further found justification for SFL's perspective on language as a meaning-making resource.

\section{Improvement of Lee's New Meta-Linguistic Knowledge Following Her Recognition of SFL's Practicality}

Most importantly, Lee's SFL-based meta-linguistic knowledge was continuously improved through her positive experiences using SFL to deconstruct or construct a chain of texts, as shown in the following interview excerpts:

When I read English academic writing papers, I can notice how cohesive ties are played out... There are also thematic patterns... and a particular choice of action verbs [as process] ... I can learn from the academic writing papers not just grammar rules. . . and I can use SFL in analyzing the cross-linguistic difference between English and Chinese through SFL-based analysis, such as a lack of cohesive devices in Chinese, and I have to avoid being influenced by it when using English.... Through SFL, I feel while there are lots of things to learn, I know what to learn and how to learn as an English major student. [Interview excerpt 6]

I thought news was objective. But when I tried to use the appraisal system to decode the meaning... I find it is not true... I feel there is always a news reporter's attitude hidden there... Their attitude can be particularly realized in the choice of verbs or adverbs. . . I could have realized this... I might just have had an intuition. . . but 
could not clearly articulate why it was the case... That was a shame for English major students. But now I can because of my SFL knowledge. [Interview excerpt 7]

The two excerpts illustrate well how Lee's meta-linguist knowledge was dynamically enhanced by her positive experiences with her language learning. In practical application she found that SFL helped her analyze texts (e.g., in-depth understanding of news reports and linguistic manifestations in academic papers) in a way that she could never have achieved with her prior knowledge; it created opportunities for her to grow as an advanced language learner (or an English major student) and be able to provide evidence-based analysis to support her arguments. Most importantly, because of the categories (e.g., cohesive devices), Lee was able to find the cross-linguistic difference between English and Chinese that could be negatively transferred to her English language practices. This further strengthened her confidence in internalizing SFLbased meta-linguistic knowledge.

\section{Practicing Meta-Linguistic Language Knowledge with English Literacy: Concrete Evidence from Lee's Dialogistic Activities and Writing}

In the process of acquiring meta-linguistic knowledge, Lee was indeed actively applying this to literacy practices. When discussing with the researcher her understanding of the text content of diverse genres, Lee always engaged in using SFL categories. This showed that she had broken free of the confines of grammatically deconstructing or constructing texts, and illuminated that she was transitioning from being a non-native EFL learner to a culturally and linguistically sensitive learner.

\section{Lee's Explicit Talk of Academic Writing and Related Analysis}

The following representative conversation segment shows how the student used SFL to understand academic texts. The original language was Chinese. However, for the readership's convenience the excerpt was translated into English:

Lee: I am reading an academic paper. It is about Vygotsky's mediation. I feel when I read it, I keep thinking about SFL.

Researcher: How so?

Lee: You see, in academic papers, we also have a particular topic; we also have to write for our audience, and organize our information. This is the register of our academic writing.

Researcher: Yes, please continue.

Lee: In response to tenor, the interpersonal meaning of academic writing is very careful. Reporting verbs, like suggest, implicate, show, have different degrees of semantic load... learners of writing have to have good knowledge of reporting verbs ... And citation is a way of supporting writers' claims and making readers trust our information. 
Researcher: That is a very nice story about your experience with interpersonal meaning in context. Anything else?

Lee: Yes, when introducing socio-cultural theory, the author used a lot of topicrelated words, such as "human" "society" and "culture" or so-called participants. . . it makes readers feel the content is clear and objective... and the process verbs such as "regulate" and "empower" are all action verbs... These verbs vigorously show how society affects human cognition.

Researcher: Nice! Really a professional account of ideational meaning in academic writing! Anything else?

Lee: Let me think. Oh, there is frequent use of cohesive devices... such as mediator and mediate, which could constitute cohesion within the paragraph. Anyway, it is written language, and readers expect it to be really fluent.

Researcher: What a great job!

This conversation between the researcher and Lee occurred during the second semester of the year-long project. At the time, Lee was already familiar with SFL. When discussing the content of academic writing with the researcher, Lee skillfully exemplified her SFL-based knowledge in analyzing the myth of academic writing, navigating the relationship between academic register, meaning, and linguistic features that are expected from dominant English communities. For instance, Lee explained the importance of choosing nouns and verbs in constructing ideational meaning as one dimension of the content of academic writing, through the terms process and participant. Not only did she use these terms, but she also explained the reasons behind such linguistic choices by commenting on the requirements of the context according to the situational variable (field) in academic writing. Similarly, by emphasizing the importance of audience in the process of writing, Lee also demonstrated her skill in understanding the interrelationship between the context of the situational variable (tenor) and the interpersonal meaning in academic writing. That is, informed by SFL in terms of the importance of a writer's alignment with readers, Lee used the term "engagement" when talking about the importance of citation and how the strength of evidence also had to be appropriately marked for readers through reporting words (show vs. implicate). Her meta-linguistic knowledge of the register variable of mode (the channel of communication) and its relation to linguistic features was also mapped in her discussion with the researcher. That is, Lee used the term cohesion when talking about lexical cohesion as illustrated between a noun (mediator) and a verb (mediate). She also explained the causal relationship between cohesion and the mode of communication, with the former being caused by the latter. In sum, while she did not become proficient in SFL, Lee transitioned from understanding SFL knowledge to unpacking the content of English language literacy and justifying her analysis, which would not have been achieved with her previous knowledge of merely structural accuracy of the English language. 


\section{Lee's Improvement of Text Constructing Skills Through the Use of SFL Knowledge}

Over the academic year, Lee gradually applied SFL-based knowledge to her language practice (e.g., reading, writing). However, the path of her transition from maintaining sentence precision to discourse appropriateness seemed to be a difficult process (field notes). For instance, in the first two writing assignments during the first month of the first semester, Lee was not yet familiar with SFL, and her writing was similar to other EFL students' writing where the emphasis was on the accuracy of individual sentences. However, the whole piece was inappropriate in terms of ideational meaning, interpersonal meaning, and cohesive devices (Fu \& Matoush, 2012; see also Table 1 below). However, through her gradual familiarity with SFL as well as the researcher's written and oral feedback, she became consistent in writing her drafts, revising her writing on her own, and submitting texts that could have appropriate meaning and good enough linguistic features endorsed by academic literacy communities (see Table 1 below).

Table 1

Changes to Lee's meta-linguistic knowledge and literacy practices

\begin{tabular}{|c|c|c|}
\hline & $\begin{array}{l}\text { Writing at the beginning of the } \\
\text { academic year }\end{array}$ & $\begin{array}{l}\text { Writing following SFL-based } \\
\text { instruction }\end{array}$ \\
\hline $\begin{array}{l}\text { Ideational } \\
\text { meaning }\end{array}$ & $\begin{array}{l}\text { No attention to logical relationships; } \\
\text { No attention to topic related lexical } \\
\text { choices or verb choices (e.g., overuse } \\
\text { of we as participant) }\end{array}$ & $\begin{array}{l}\text { Control of process verbs by using } \\
\text { action verbs; } \\
\text { Control of participants by using } \\
\text { topic related lexical choices (e.g., } \\
\text { less frequent use of we as subject) }\end{array}$ \\
\hline $\begin{array}{l}\text { Interpersonal } \\
\text { meaning }\end{array}$ & $\begin{array}{l}\text { No knowledge of citations; } \\
\text { No knowledge of graduated verbs (i.e., } \\
\text { verbs are either be or not be; there is } \\
\text { a lack of verbs between be or not be, } \\
\text { such as seem, could) }\end{array}$ & $\begin{array}{l}\text { Appropriate use of engagement } \\
\text { through citations to support her } \\
\text { claims (e.g., her use of information } \\
\text { from news and research papers to } \\
\text { support her claims); } \\
\text { Control of semantic load by using } \\
\text { diverse verbs or modal verbs such } \\
\text { as say, show, implicate, seem, and } \\
\text { could }\end{array}$ \\
\hline $\begin{array}{l}\text { Textual } \\
\text { meaning }\end{array}$ & $\begin{array}{l}\text { Almost no awareness of theme-rheme } \\
\text { progression; } \\
\text { Limited cohesive ties, especially lexical } \\
\text { ties (i.e., loose connections between } \\
\text { sentences) }\end{array}$ & $\begin{array}{l}\text { Use of constant theme (i.e., } \\
\text { repeating the same theme) to } \\
\text { achieve cohesion; } \\
\text { Good use of cohesive ties (i.e., } \\
\text { conjunctions or lexical chains) in } \\
\text { making coherent texts }\end{array}$ \\
\hline
\end{tabular}

As shown in Table 1, at first, Lee was constrained by her previous meta-linguistic knowledge that was focused on structural accuracy; her writing displayed a departure from academic register and linguistic manifestations. At the linguistic level, she had no clear awareness of the difference between spoken and written English (e.g., a lack of strong connection between sentences). The student's first language experiences may have also influenced her English writing. Indeed, Chinese is writer-centered and readers 
are expected to decode meaning; it also makes limited use of cohesive devices (Lian, 1993). At the interpersonal level, Lee also did not possess the skills of effectively and appropriately conveying information to readers. Her writing expressed either positive (e.g., is) or negative meaning (e.g., is not), without using verbs denoting levels of meaning between is and is not (e.g., seem, could). Her ideational meaning was fine although logical relationships between sentences were not spelled out from time to time, which may also be due to the preference for implicit logical relationships in her first language (Lian, 1993). However, in the course of the academic year Lee applied her SFL-knowledge in her writing. At the ideational level, her writing later showed clear logical relationships. At the interpersonal level, she also frequently used graduated verbs (e.g., seem), stating her claim when evidence was not strong enough. At the textual level, she used lexical and grammatical cohesion to tighten up her writing. In other words, Lee obviously was able to follow her newly gained meta-linguistic knowledge, gradually applying it across her writing, which helped her overcome constraints from her previous English language education as well as her fist language learning experiences.

\section{Discussion}

This study explored how SFL affected a tertiary EFL student's appropriation of new meta-linguistic knowledge and her literacy practices. One finding of the year-long case study was that Lee was open to the SFL-based meta-linguistic theory and was motivated to be a passionate language learner because of her newly gained knowledge of language. This echoes findings in the context of ESL, where a positive relationship between students' SFL-based meta-linguistic knowledge and practices has been identified (cf., Chen \& Myhill, 2016; Gebhard et al., 2014; Humphrey \& Macnaught, 2016). This also adds to the scarce literature on using SFL in developing students' metalinguistic knowledge in tertiary EFL contexts (cf., Humphrey et al., 2016). In addition, unlike studies finding students resisting new knowledge that is much different from their previous learning experiences (e.g., Margolis, 2001; Zembylas, 2008), this study shows the importance of maintaining sound principles, which attend to students' current language levels and their abilities of advancement. In this way students did not have much difficulty transitioning to a new perspective on language (cf., Gebhard, 2010; Macken-Horarik, 2012). Most importantly, in the field of language education the relationship between self, professional identity, and students' motivation has been emphasized, but limited instructional strategies have been presented in empirical studies (cf., Tran, 2007; Ushioda, 2011). In this study the SFL-based meta-linguistic knowledge helped the student acquire positive experiences in practicing English literacy and motivated her to further invest herself in challenging her own limits in understanding the complexity of SFL and to continue learning about the English language as an English major student, rather than to simply focus on grammar. In other words, the study also uniquely provides a linguistic approach in developing the triadic relationship between English language learners' identity, motivation, and self-agency. 
In addition, another finding of the study shows that SFL meta-linguistic knowledge, which bridges sentence accuracy, linguistic choices, and meaning-making in context, expanded the student's previous knowledge and facilitated her language practices. For instance, the new knowledge offered her an accessible tool to improve English literacy. Because of the refreshed knowledge, Lee was able to provide evidence-based claims as an EFL learner. In other words, contrary to the conventional claim that EFL students are passive receivers of information, Lee went beyond the constraints of her first language culture, in which claims without evidence often occur in daily communication (cf., Lian, 1993; Zhang, 1999). This echoes recent findings that EFL students also become eager to be language learners who are able to think critically (cf., Stapleton, 2002). Furthermore, by relying on her SFL knowledge, Lee proved herself as a culturally and linguistically adapted member of internationally acknowledged English language communities. Specifically, Lee's practice-based skill improvement further demonstrated the power of SFL in improving language learners' literacy and provided a tool for educators who are struggling to improve EFL learners' linguistic skills in accordance with the expectations from English language communities (Fu \& Matoush, 2012; Zhang, 2017). Most importantly, Lee's refreshed knowledge and positive experiences further fed into her confidence, acting as a gate-holder of SFL-based meta-linguistic knowledge. In other words, Lee's case also complements our understanding that practice-based experience is a catalyst for students' improved understanding of a theory, motivating them to continue applying it in their future studies (cf., Negretti, 2012).

The implications of this research include three dimensions. First, as high-stakes tests in many EFL contexts favor linguistic accuracy, students might mistakenly think their role as an English learner is to only refine their knowledge of sentence structure and perform well on tests. For the sake of students' long-term interests in English communities, particularly for advanced language learners at the tertiary level who already have goodenough grammar knowledge, it is imperative for educators to complement students' meta-linguistic knowledge, such as with the tenets from SFL. The ultimate purpose of diversifying language learners' meta-linguistic knowledge is to have them meet the communication expectations in native English speaking communities, such as being able to construct meaningful discourse as a writer and decode hidden meanings in texts through analysis. Second, the study also suggests that students need to go out of their comfort zone and reconstruct their meta-linguistic knowledge. Indeed, reconstructing meta-linguistic knowledge is not without its hurdles (Chen \& Myhill, 2016; Gebhard, 2010). Students, especially advanced language learners when guided in seeing the benefits of SFL, must be motivated to challenge themselves. However, as Ushioda (2010) noted, "motivation is shaped by desirable self-images in social, personal or professional contexts of L2 use" (p. 30). In other words, students' meta-linguistic knowledge change is contingent upon their agency in realizing the importance of achieving language identity recognized by a dominant English community. Third, despite the emphasis of many EFL high-stakes tests on language accuracy, language educators should create an environment 
in which students can have hands-on experiences with new meta-linguistic knowledge (e.g., SFL), through which educators can observe whether the new knowledge benefits EFL students' success in English academic literacy.

\section{Conclusions}

This study centers on the argument that instead of focusing on their success on decontextualized grammar, EFL language students should be taught appropriate metalinguistic knowledge and be prepared for the challenges of being members of authentic English language communities. Through a one-year project examining an EFL student's experiences with explicit instruction of the SFL-based perspective on language as meaning-making in context, the study has two important conclusions to draw, adding to still insufficient amounts of research on transforming EFL learners' meta-linguistic knowledge and practices for the purpose of their adjustment to dominant English communities. First, the study shows that the language learner who already had good knowledge of grammatical rules at the sentence level, enthusiastically involved herself in acquiring SFL-based meta-linguistic knowledge. The process of acquiring the new knowledge was catalyzed with an array of internal and external factors, such as the student's passion for constructing her professional identity, self-agency in reflecting on the previous learning experiences with the English language, and the student's awareness of the power of SFL-based meta-linguistic knowledge in English learning, which provided her with a broader perspective. Secondly, the study shows that, when guided by an SFL-based perspective on language features, contexts, and meaning-making in texts, the EFL student was able to go beyond her previous knowledge that focused on learning grammatical rules or accumulating new words. That is, she transformed into a linguistically and culturally sensitive language learner in terms of using SFL to talk about texts, make evidence-based arguments, or utilize the SFL-based knowledge to demonstrate English language literacy as expected by authentic English language communities.

Future studies could focus on SFL-based action research among in-service or preservice teachers who are trained to implement the corresponding practices in language teaching classrooms, and assist students in combining traditional knowledge on structural accuracy with good-enough knowledge of SFL, for the purpose of meeting the challenges of authentic English language communities (Macken-Horarik, 2012).

\section{Acknowledgment}

The project is funded by a grant from MOE (Ministry of Education in China) key project of humanities and social sciences (16JJD740002) 


\section{References}

Aunurrahman, A., Hamied, F., \& Emilia, E. (2017). Exploring the tertiary EFL students' academic writing competencies. Indonesian Journal of Applied Linguistics, 7(1), 72-79. https://doi.org/10.17509/ijal.v7i1.6860

Chen, H., \& Myhill, D. (2016). Children talking about writing: Investigating metalinguistic understanding. Linguistics and Education, 35, 100-108. https://doi.org/10.1016/j. linged.2016.07.004

Christie, F., \& Martin, J. R. (Eds). (2009). Language, knowledge and pedagogy: Functional linguistic and sociological perspectives. London/New York: Continuum.

Creswell, J. W., \& Poth, C. N. (2017). Qualitative inquiry and research design: Choosing among five approaches. Thousand Oaks, CA: Sage.

Dreyfus, S. J., S. Humphrey, S., Mahboob, A., \& Martin, J. R. (2015). Genre pedagogy in higher education: The SLATE project. Basingstoke: Palgrave Macmillan.

Fang, Z., \& Schleppegrell, M. (2010). Disciplinary literacies across content areas: Supporting secondary reading through functional language analysis. Journal of Adolescent \& Adult Literacy, 53(7), 587-597. https://doi.org/10.1598/JAAL.53.7.6

Fu, D., \& Matoush, M. (2012). Teachers' perceptions of English language writing instruction in China. In C. Bazerman, C. Dean, J. Early, K. Lunsford, S. Null, P. Rogers, \& A. Stansell (Eds), International Advances in Writing Research: Cultures, Places, Measures (pp. 23-40). Fort Collins, Colorado: The WAC Clearinghouse and Parlor Press.

Gebhard, M. (2010). Teacher education in changing times: A systemic functional linguistics (SFL) perspective. TESOL Quarterly, 44(4), 797-803. https://doi.org/10.5054/tq.2010.237335

Gebhard, M., Chen, I-An., \& Britton, L. (2014). "Miss, nominalization is a nominalization": English language learners' use of SFL metalanguage and their literacy practices. Linguistics and Education, 26, 106-125. https://doi.org/10.1016/j.linged.2014.01.003

Gebhard, M., Gunawan, W., \& Chen, I-An. (2014). Redefining conceptions of grammar in English education in Asia: SFL in practice. Applied Research on English Language, 3(2), 1-17.

Halliday, M. A. K. (1994). Introduction to functional grammar (2nd ed.). London: Edward Arnold.

Harklau, L. (2000). From the 'good kids' to the "worst”: Representations of English language learners across educational settings. TESOL Quarterly, 34(1), 35-67. https://doi. org/10.2307/3588096

Humphrey, S., \& Macnaught, L. (2016). Functional Language Instruction and the writing growth of English language learners in the middle years. TESOL Quarterly, 50(4), 792-816. https://doi.org/10.1002/tesq.247

Hyland, K. (2002). Authority and invisibility: Authorial identity in academic writing. Journal of Pragmatics, 34(8), 1091-1112. https://doi.org/10.1016/S0378-2166(02)00035-8

Lian, S. (1993). Contrastive studies of English and Chinese. Beijing: Higher Education Press.

Macken-Horarik, M. (2012). Why school English needs a 'good enough' grammatics (and not more grammar). Changing English, 19(2), 179-194. https://doi. org/10.1080/1358684X.2012.680760

Margolis, E. (Ed.). (2001). The hidden curriculum in higher education. New York: Routledge. 
Martin, J. R., \& White, P. R. (2005). Language of evaluation: Appraisal in English. London: Palgrave Macmillan. https://doi.org/10.1057/9780230511910

Moore, J., \& Schleppegrell, M. (2014). Using a functional linguistics metalanguage to support academic language development in the English Language Arts. Linguistics and Education, 26, 92-105. https://doi.org/10.1016/j.linged.2014.01.002

Negretti, R. (2012). Metacognition in student academic writing: A longitudinal study of metacognitive awareness and its relation to task perception, self-regulation, and evaluation of performance. Written Communication, 29(2), 142-179. https://doi. org/10.1177/0741088312438529

Rose, D., \& Martin, J. R. (2012). Learning to write, reading to learn: Genre, knowledge and pedagogy in the Sydney school. London: Equinox.

Schleppegrell, M., Achugar, M., \& Oteíza, T. (2004). The grammar of history: Enhancing content-based instruction through a functional focus on language. TESOL Quarterly, 38(1), 67-93. https://doi.org/10.2307/3588259

Stapleton, P. (2002). Critical thinking in Japanese L2 writing: Rethinking tired constructs. ELT Journal, 56(3), 250-257. https://doi.org/10.1093/elt/56.3.250

Tran, L. (2007). Learners' motivation and identity in the Vietnamese EFL writing classroom. English Teaching: Practice and critique, 6(1), 151-163.

Ushioda, E. (2011). Language learning motivation, self and identity: Current theoretical perspectives. Computer Assisted Language Learning, 24(3), 199-210. https://doi.org/10.10 $\underline{80 / 09588221.2010 .538701}$

Yasuda, S. (2015). Exploring changes in FL writers' meaning-making choices in summary writing: A systemic functional approach. Journal of Second Language Writing, 27, 105-121. https://doi.org/10.1016/j.jslw.2014.09.008

Zembylas, M. (2008). Engaging with issues of cultural diversity and discrimination through critical emotional reflexivity in online learning. Adult Education Quarterly, 59(1), 61-82. https://doi.org/10.1177/0741713608325171

Zhang, L. (1999). A comparison of US and Chinese university students' cognitive development: The cross-cultural applicability of Perry's theory. The Journal of Psychology, 133(4), 425-439. https://doi.org/10.1080/00223989909599753

Zhang, X. (2017). Exploring a novice Chinese EFL teacher's writing beliefs and practices: A systemic functional perspective. International Journal of Language Studies, 11(1), 95-118.

\section{Xiaodong Zhang}

Beijing Foreign Studies University,

School of English and International Studies

19 North Xisanhuan Avenue, Beijing, China

zxdman588@gmail.com 


\section{Preoblikovanje metalingvističkog znanja i metoda učenja engleskoga kao stranoga jezika na tercijarnoj razini: longitudinalna studija slučaja}

\section{Sažetak}

Ovo istraživanje govori o načinu na koji je eksplicitno poučavanje upotrebe jezika putem stvaranja značenja u kontekstu (tj. upotrebe jezika kao dinamične interakcije između konteksta, značenja i lingvističkih obilježja) utjecalo na metalingvističko znanje studentice engleskoga kao stranoga jezika na tercijarnoj razini, kao i njezinih metoda učenja jezika. Utemeljeno na kvalitativnoj analizi intervjua, razgovora $i$ pisanih uzoraka skupljenih tijekom jedne akademske godine od učenice engleskoga kao stranoga jezika na fakultetskoj razini, istraživanje pokazuje da je stjecanje nove metalingvističke perspektive upotrebe jezika kao stvaranja značenja u kontekstu što se razlikovalo od prijašnjih spoznaja upotrebe jezika kao dekontekstualizirane rečenične točnosti - bio proces interakcije s različitim čimbenicima. Ti su čimbenici uključivali njezinu strast za izazovnim zadatcima i izgradnjom vlastitog profesionalnog identiteta. Dodatno, tijekom godine, učenica je također usvojila odgovarajuću razinu jezične pismenosti koja se podudara s prihvaćenom jezičnom pismenošću cijenjenom u autentičnim engleskim jezičnim zajednicama.

Ključne riječi: engleski kao strani jezik; učenici jezika; stvaranje značenja; sistemska funkcionalna lingvistika; tranzicija.

\section{Uvod}

U kontekstu engleskoga kao stranoga jezika (ESJ) mnogi su učenici od osnovne do tercijarne razine izloženi učenju i poduci gramatičkih pravila pri konstrukciji/ dekonstrukciji rečenica u pisanju i čitanju tekstova (Aunurrahman, Hamied i Emilia, 2017; Fu i Matoush, 2012; Tran, 2007; Yasuda, 2015). U opisanoj situaciji učenici ESJ stječu ograničeno lingvističko znanje o učinkovitom učenju jezika pa stoga ne uspijevaju ispuniti akademska očekivanja autentičnih engleskih zajednica u kojima tražena jezična pismenost (npr. čitanje i pisanje) podrazumijeva učenika koji poznaje složene odnose između jezičnih resursa i konteksta, kao i kulturu engleskoga jezika (Moore i 
Schleppegrell, 2014; Schleppegrell, Achugar i Oteíza 2004). Nadalje, mnogi studenti, koji već imaju adekvatno znanje o održavanju strukturalne točnosti, žele zadovoljiti zahtjeve izgradnje vlastitog identiteta kao naprednih učenika engleskoga jezika (Tran, 2007; Zhang, 2017). Ipak, kao rezultat izloženosti kontinuiranom poučavanju gramatičkih pravila, počinju sumnjati u sebe i sve su manje motivirani za nastavak učenja (Harklau, 2000; Humphrey i Macnaught, 2016; Hyland, 2002; Ushioda, 2011). Drugim riječima, postoji neodgodiva potreba za osvježavanjem metalingvističkog znanja studenata, učenika ESJ (tj. teorijske perspektive jezika na koju se učenici oslanjaju pri razumijevanju i učenju jezika) (Negretti, 2012) povećanjem njihove jezične izvedbe kao učenika engleskoga jezika kakav podupiru autentične akademske engleske zajednice, zatvarajući „jaz u postignuću između govornika dominantnih i nedominantnih varijanti engleskog” (Humphrey i Macnaught, 2016, str. 21).

\section{Teorijski okvir}

\section{Sistemska funkcionalna lingvistika:}

\section{Nadopunjavanje razumijevanja jezika učenika}

Sistemska funkcionalna lingvistika (SFL) (Halliday, 1994; Martin i White, 2005; Rose i Martin, 2012) promatra metalingvističko znanje korisnika jezika iz perspektive stvaranja značenja. SFL naglašava nužnost metalingvističkog znanja korisnika jezika o samom jeziku kao smislenim cjelinama koje se javljaju u interakcijama između konteksta, značenja i lingvističkih značajki (gramatike i vokabulara), uz eksplicitni okvir koji taj mehanizam objašnjava.

Specifično, SFL okvir uključuje konstrukte konteksta situacije (tj. registar), tri metaznačenja, leksik i gramatiku i kontekst kulture (tj. žanr). Kontekst situacije (tj. registar) opisuje informacije o kontekstu neposredne situacije povezane $s$ komunikacijskom aktivnošću i uključuje tri varijable: polje (tj. glavnu temu jezičnih aktivnosti), tenor/sadržaj (tj. interpersonalni odnos uključen u jezične aktivnosti) i modus (tj.jezični kanal). Usidren tim trima varijablama jezik se kao značenjska jedinica predstavlja u tri aspekta: (1) idejno značenje (tj. semantičko utjelovljenje polja koje se fokusira na korisnikovo znanje o jezičnom događaju); (2) interpersonalno značenje (tj. semantičko utjelovljenje sadržaja koje se odnosi na korisnikove interakcijske uzorke i evaluacijski stav prema jezičnom događaju); i (3) tekstualno značenje (tj. semantičko predstavljanje modusa s fokusom na informacijskom tijeku jezičnih događaja). U procesu konstruiranja triju značenja SFL daje leksik i gramatiku (više iznijansirane kategorije), što objašnjava tri metaznačenja jezičnih događaja.

U dekonstrukciji/konstrukciji idejnog značenja glavni leksičko-gramatički kodovi uključuju sudionika (imeničke skupine), proces (glagol) i okolnosti (prijedložne skupine). Slično tomu, interpersonalno značenje ostvaruje se kodovima poput subjekta (imenice) i predikata, kao i dodataka (priložne ili prijedložne skupine). Redoslijed subjekta i predikata pokazuje interakcijski uzorak (npr. subjekt - predikat = izjavna rečenica, a predikat - subjekt $=$ pitanje). Unutar interpersonalne dimenzije postoji također 
sustav vrednovanja kojim se kodira korisnikov evaluacijski stav; šifre uključuju stav (riječi koje označavaju ili naznačuju stav), stupnjevanje (riječi koje znače ili naznačuju stupanj leksičkog značenja) i angažman (riječi koje označavaju ili naznačuju izvor ili sigurnost informacije). Tekstualno značenje stvara se iz kodova poput teme (početak rečenice koji u najmanju ruku uključuje element temeljnog sadržaja) ili kohezivnih veza koje uključuju gramatičke kodove (npr. veznici) i leksičke kodove (npr. sinonimi ili antonimi).Značenje ostvareno putem leksika i gramatika u kontekstu situacije također je organizirano u određene etape kako bi se postigla specifična društvena svrha (npr. kulturološki postupci s ciljem postizanja određene svrhe u nekoj jezičnoj zajednici).

\section{Pregled literature}

Budući sa načela SFL-a uspješno odražavaju kurikularne zahtjeve koji se fokusiraju na izobrazbu učenika za razumijevanje smislenog sadržaja i odgovarajućih jezičnih značajki u dominantnim zemljama engleskog govornog područja, poput Sjedinjenih Država i Australije, na SFL-u utemeljeno poučavanje engleskoga jezika u tim zemljama široko se primjenjuje (npr. Chen i Myhill, 2016; Dreyfus, Humphrey, Mahboob i Martin, 2016; Fang i Schleppegrell, 2010; Gebhard, Chen i Britton, 2014). Kao što su Schleppegrell i suradnici (2004) primijetili: „ovo (SFL) je čvrsta podloga za inkorporaciju eksplicitnog fokusa o tome kako se jezik koristi u različitim predmetnim područjima za konstruiranje specifičnih vrsta značenja." Na primjer, u istraživanju Gebharda i suradnika (2014) učenici engleskoga kao drugoga jezika (EDJ) na elementarnoj razini, a čiji je prvi jezik bio španjolski, postali su napredni učenici u čitanju i pisanju. Navedeno su pokazali njihovi spretni manevri u dekodiranju ili kodiranju jezika kao sredstva stvaranja značenja, uključujući leksičke izbore u kontekstu (poput učeničkih primjera poznavanja i upotrebe specifičnih glagola u pisanju i čitanju znanstvenih objašnjenja). $U$ australskoj urbanoj srednjoj školi 18-omjesečno longitudinalno istraživanje koju su Humphrey i Macnaught (2016) provele s učenicima ESJ, koji su imali ograničeno metalingvističko i na SFL-u utemeljeno znanje, pokazalo je njihov napredak u čitanju i pisanju putem rasprava s njihovim učiteljima utemeljenima na SFL-u, a što se odrazilo na njihovo čitanje i pisanje, npr. poznavanje jezične funkcije kojom se izražava kontrast (npr. iako) i primjenu uključenosti (npr. moguće). Za razliku od konteksta engleskoga kao drugoga jezika, istraživanja u kontekstu ESJ još su uvijek ograničena. Aunurrahman i suradnici (2017) pokazali su da se pisanje indonezijskih studenata na fakultetu popravilo tijekom poučavanja utemeljenog na SFL-u, za što je bio primjer njihova dobra kontrola lingvističkih osobina u tri vrste pisanja (ekspozicija, rasprava i osvrt na književna djela), a odrazila se u studentskoj upotrebi tema-komentar/fokus uzoraka pri oblikovanju fluentnih tekstova prema zahtjevima različitih žanrova.

Kao što je vidljivo iz prethodno spomenutih istraživanja, obilje literature o kontekstu EDJ pokazalo je moć SFL-a u razvoju metalingvističkog znanja učenika jezika, kao i u pomoći pri postizanju uspjeha u pismenosti na engleskome jeziku (npr. pisanju i čitanju). Suprotno tomu, istraživanja u kontekstu ESJ, posebno na tercijarnoj razini, još 
su uvijek ograničena jer se većina kurikulskih zahtjeva još uvijek fokusira na strukturalnu točnost ili, u nekim slučajevima, obrazovanje učitelja još uvijek nije učinkovito provedeno (Tran, 2007; Zhang, 2017). Čak je i među limitiranim istraživanjima o poučavanja ESJ na tercijarnoj razini (npr. Aunurrahman i drugi, 2017; Yasuda, 2015) prevladavajući fokus na lingvističkim obilježjima promjena u učeničkom pisanju, odvajajući učeničko metalingvističko znanje od njihove stvarne uporabe jezika. S obzirom na navedeno postojeće stanje, još uvijek nedostaje uvida u način na koji promjene metalingvističkog znanja jezičnih učenika na tercijarnoj razini utječu na njihovu jezičnu praksu, iako ,je ono što će učenici razviti kao kognitivne resurse za buduće aktivnosti pod utjecajem onoga čega su postali svjesni” (Chen i Myhill, 2016, str. 101). S obzirom na postojeću istraživačku prazninu u kontekstu ESJ-a, kao i imperativnu potrebu za pripremom učenika ESJ na tercijarnoj razini za ispunjavanje zahtjeva pismenosti engleskih jezičnih zajednica, ovaj rad predstavlja longitudinalnu studiju slučaja studentice i učenice engleskoga kao stranoga jezika te njezina iskustva sa sistemsko-funkcionalnom lingvistikom. Istraživanje se temelji na sljedeća dva međusobno isprepletena istraživačka pitanja:

(1) Kako studentica engleskoga kao stranoga jezika reagira na kurikul utemeljen na SFL-u, čiji je cilj razvoj učeničkih metalingvističkih znanja o engleskome jeziku?

(2) Utječe li i kako metalingvističko znanje studentice engleskoga kao stranoga jezika utemeljeno na SFL-u na njezinu uporabu engleskoga jezika?

\section{Metodologija}

\section{Sudionici i kontekst istraživanja}

Lee, učenica ESJ prikazana u ovom istraživanju, bila je uključena u projekt kao studentica druge godine studija engleskoga jezika. Lee je bila zainteresirana za učenje engleskoga, i u početku je bila zadovoljna što studira engleski na jednom od najboljih sveučilišta u Kini. Ipak, na drugoj godini studija osjetila je da zapada u kolotečinu: nije više znala kako učiti jer je još uvijek bila uključena u jezično obrazovanje slično srednjoškolskom (npr. učenje riječi ili fokusiranje na strukturalnu točnost) (usp. Zhang, 2017). Rekla je kako to može naučiti sama i stvarno je željela postati napredan učenik koji bi mogao učinkovito komunicirati s izvornim govornicima engleskoga jezika (Ushioda, 2011; Tran, 2007). Drugim riječima, Lee se suočila s neodgodivom potrebom za unapređenjem svoga znanja engleskoga jezika i izgradnjom vlastitog profesionalnog identiteta kao studentice engleskoga jezika.

U proljeće 2016. Lee je počela pohađati akademski kolegij pisanja kod istraživača u ovome projektu. U toj je grupi SFL bio nov svim studentima, a medijator u njegovu poučavanju bio je autor ovoga rada koji je imao za cilj povezati sadržaj SFL-a s prijašnjim učenjem jezika studenata te osvježiti njihovo metalingvističko znanje. Iako u SFL-u postoje mnogi termini, tijekom kolegija koristila se minimalna terminologija i mnogi su termini, kada je bilo potrebno, prevedeni na materinski jezik studenata. Tijekom cijelog semestra podučavali su se glavni konstrukti SFL-e: žanr, registar, tri meta- 
funkcije, leksik-gramatika, kao i međusobne veze između tih konstrukata. Glavni lingvistički termini (npr. tema, kohezivne veze, sudionik i stupnjevanje), koji su se koristili za kodiranje/dekodiranje tri metaznačenja, također su podučavani. Paralelno s kolegijem, Lee je također entuzijastično pohađala radionicu koju je vodio autor ovoga rada, a koja je poboljšala njezino poznavanje SFL-a. U drugom semestru, iako više nije pohađala kolegij pisanja, Lee je još uvijek entuzijastično nastavila učenje SFL-a i njegove primjene na široki spektar žanrova. Tijekom akademske godine, uz nastojanja da usvoji metalingvističko znanje utemeljeno na SFL-u, Lee je primjenjivala SFL kako bi analizirala raznolike vrste tekstova, od argumentacije i priče do novinskog izvještaja. Zbog toga je bila odabrana kao najprimjereniji sudionik za ovaj projekt.

\section{Prikupljanje podataka i analiza}

Podatci su prikupljani mjesečno tijekom akademske godine, osim u vrijeme zimskih praznika. Posebno, kao dodatak intervjuima, razgovori istraživača s Lee također su snimani, a u njima je raspravljala o svom kontinuiranom razumijevanju engleske pismenosti u odnosu na perspektivu utemeljenu na SFL-u. Razgovori i intervjui ponajprije su se odvijali na studentičinu materinskom jeziku (tj. kineskom). Dodatno, Leeini pisani radovi tijekom godine također su prikupljeni, uključujući njezine pisane analize multižanrovskih tekstova (na engleskome jeziku), poput analiza lingvističkih osobina novinskoga izvještaja, raspravljačkih tekstova, govorenoga jezika i njezine pisane osvrte na lingvističke razlike između engleskoga i njezina materinskog jezika. Analiza podataka uglavnom je bila kvalitativna i na jeziku na kojem su prikupljeni (Creswell i Poth, 2017). Leeini intervjui i razgovori su transkribirani i čitani više puta prije nego su identificirane kategorije. Važne kategorije su tada kombinirane kako bi se utvrdile teme kroz niz grupa podataka. Leeino pisanje i pisane analize prikupljene su i analizirane kako bi se utvrdilo njezino metalingvističko znanje utemeljeno na SFL-u (Christie i Martin, 2009). Kao dodatak, također su analizirane bilješke s terena tijekom akademske godine zbog olakšavanja analize podataka.

\section{Rezultati}

Kao rezultat jednogodišnje izloženosti posredovanom učenju SFL-a i povezanih postupaka, Lee je stekla metalingvističko znanje utemeljeno na SFL-u, koje je nadopunilo njezino predznanje dekontekstualizirane gramatike. Proces razvoja njezina metalingvističkog znanja bio je interakcija između njezina razočaranja u samu sebe kao studentice engleskoga jezika s ograničenim znanjem jezika i njezine motivacije da se poveže s izvornim engleskim zajednicama. Sljedeće su teme odabrane kako bi ilustrirale rezultate povezane uz definirana istraživačka pitanja.

\section{Leeino prihvaćanje nove jezične teorije zbog samosvijesti o vlastitom limitiranom znanju}

Leeino metalingvističko znanje bilo je ograničeno na gramatička pravila rečenica ili stjecanje novoga vokabulara iz engleskoga jezika, s posebnim naglaskom na održavanju 
strukturalne točnosti. Ipak, Leeino iskustvo s ograničenom moći njezin postojećeg jezičnog repertoara $\mathrm{u}$ ispunjavanju napredne razine pismenosti u engleskom (npr. čitanje) dovelo ju je do akumuliranja novog i učinkovitog metalingvističkog znanja. Kako je Lee rekla:

Prije nego sam došla na fakultet, svi moji učitelji engleskog uvijek su naglašavali učenje strukturalnih pravila ili nam govorili da pamtimo napredni vokabular... Na sveučilištu mnogi su se moji učitelji (tijekom prve godine) još uvijek koristili sličnim metodama... To mi je bilo dosadno i u tom području već sam imala veliko znanje... mogla sam jednostavno sve naučiti sama; zašto bih išla na fakultet?... Zaista trebam nove metode poučavanja. [Prvi isječak iz intervjua]

Drugim riječima, kao studentica koja je već dobro poznavala strukturalna pravila i posjedovala svijest o zapamćivanju vokabulara, prijelazom na fakultet očekivala je nove ili učinkovitije načine razumijevanja engleskoga jezika. Ipak, tijekom njezine prve godine poučavanje je još uvijek primarno bilo uz pomoć strukturne gramatike ili akumulacije vokabulara. Posljedica toga je da je Lee bila razočarana postojećim metodama poučavanja i spremna prihvatiti novi pristup engleskome jeziku.

\section{Strast za novim pristupom jeziku s namjerom izgradnje vlastitog profesionalnog identiteta}

Kao studentica engleskoga jezika Lee je bila samopouzdana u smislu vlastitoga znanja gramatičkih pravila. Ipak, u isto je vrijeme sumnjala u mogućnost daljnjeg poboljšanja svoga znanja engleskoga jezika nadogradnjom postojećega znanja sa svrhom izgradnje vlastitog profesionalnog identiteta, a što pokazuje sljedeći isječak iz intervjua:

Još sam uvijek samopouzdana kao studentica engleskoga jezika. Oni (koji ne studiraju engleski) možda dobro čitaju i također poznaju gramatiku i mnoge riječi... (ali) ne govore dobro u smislu izgovora... Međutim, također sam zabrinuta.... smatram kako je to jedina stvar koja me razlikuje od njih.... uvijek razmišljam o tome kako poboljšati svoje znanje engleskoga. Čak pri govoru nekada imam problem sa sadržajem, iako mi je izgovor dobar. Ne želim s prijateljima ili budućim učenicima razgovarati samo o gramatici ili vokabularu. Stvarno želim biti poput izvornih govornika ili korisnika jezika. [Drugi isječak iz intervjua]

Kao što je vidljivo iz tog isječka intervjua, Lee je bila samopouzdana jer studira engleski i njezino je samopouzdanje bilo utemeljeno na sposobnosti fonetske artikulacije engleskoga jezika. Ipak, njezino samopouzdanje nije ju zaslijepilo. Umjesto toga je aktivno razmišljala o svom identitetu studentice engleskoga jezika i bila voljna izgraditi ga na profesionalan način koji bi je u konačnici doveo do integracije u autentične engleske akademske zajednice. 


\section{Početni izazovi u razumijevanju SFL-a}

Iako je Lee bila otvorena za usvajanje nove teorije, borila se $s$ razumijevanjem teorije u učionici i izvan nje. Ipak, njezine teškoće s novom teorijom bile su ublažene nastavničkim posredovanim poučavanjem i njezinim samoposredovanjem. Kako je rekla:

Bilo je trenutaka kada sam imala teškoća u razumijevanju te teorije. Puno je termina... i potpuno razumijevanje teorije nije jednogodišnje, a imam i druge kolegije kojima se moram baviti... Ali kao studentica engleskog moram se razvijati. Srećom, Vi (istraživač) ste također poučavali... SFL.... u i izvan učionice na zaista prihvatliv način... Sigurna sam da nisam potpuno razumjela teoriju, ali znam glavne sastavnice. [Treći isječak iz intervjua]

Kako pokazuju isječci iz intervjua, SFL kao teorija sama po sebi je za Lee, koja nije imala iskustva s drugim sličnim jezičnim teorijama, bila zahtjevna. Za razliku od učenja gramatičkih pravila sintakse, u pristupu koji se poučavao od osnovne i srednje škole (tj. šest godina), ovo je bilo prvi put da je iskusila relativno složenu teoriju unutar jednogodišnjeg razdoblja. Ipak, njezina odlučnost da postane uspješna studentica engleskoga jezika poticala je njezine ambicije u procesu učenja. Također, učiteljsko posredovanje utemeljeno na običnom jeziku (studentičin materinski jezik) povećalo je njezino samopouzdanje u učionici i izvan nje.

\section{Leeino razumijevanje jezika kao sredstva stvaranja značenja}

Tijekom vremena, zbog izloženosti SFL-u u učionici i izvan nje, Lee je postupno prešla granice svog predznanja engleskoga jezika i stekla novu konceptualizaciju upotrebe jezika kao dinamičnu interakciju između konteksta, jezika i gramatike/leksika. Jedna tema koja se iznova javljala pri intervjuima s Lee o oblikovanju njezina novog metalingvističkog znanja prikazana je u sljedećem:

Naravno, moramo održati strukturalnu točnost u pisanom jeziku. Ali kontekst je važan za upotrebu jezika... ne možemo govoriti kako želimo... ne možemo pisati kako želimo... ne možemo pisati što želimo... i kada čitamo, ne možemo samo upotrebljavati intuiciju pri dekodiranju značenja... korisnici jezika moraju znati da je upotreba jezika povezana sa značenjem... i značenje koje se dosegne lingvističkim izborima mora biti prihvaćeno od strane engleske zajednice... konstrukti... žanr, registar, tri značenja i njihovi odnosi s vokabularom i gramatikom sve je važno za nas kao učenike jezika. [Četvrti isječak iz intervjua]

Kao što pokazuje ta opetovana tema tijekom njezine jednogodišnje interakcije s istraživačem, Lee je očito bila sposobna rekonceptualizirati jezik izlazeći izvan granica isključivo pažnje za mehaničku točnost rečenica ili akumuliranje riječi. Drugim riječima, za Lee je učenje engleskoga jezika (npr. govorenje, pisanje i čitanje) postalo povezano $s$ vještom kontrolom jezičnog korisnika lingvističkih obilježja (vokabulara i gramatike) pri postizanju kontekstualno primjerenih značenja putem različitih kanala jezične komunikacije. 


\section{Leeino napredno razumijevanje metalingvističkih koncepata utemeljenih na SFL-u kao rezultat promišljanja osobnog repertoara znanja}

Kao studentica engleskoga jezika Lee nije samo pasivno usvajala novi sadržaj na SFL-u. Umjesto toga, njezino je stjecanje znanja utemeljenog na SFL-u bilo popraćeno razmišljanjem o ulozi koju tako utemeljeno znanje ima u stvarnoj jezičnoj pismenosti. Kako je Lee rekla:

Posebno u čitanju, ponekad su se naši učitelji oslanjali samo na svoje osjećaje pri tumačenju značenja teksta... pri poučavanju teksta moj je učitelj jednom rekao da krava koja uzdiše ukazuje na određeno značenje... Ipak, SFL nam daje puno kategorija na koje se mogu osloniti, poput sustava vrednovanja; njime se mogu koristiti kako bih pokazala autorov evaluativni stav ili mišljenje... SFL je uvjerljiviji... Također sam razmišljala o stvaranju značenja u kineskom jeziku $i$ oni mi (konstrukti utemeljeni na SFL-u) pomažu da utvrdim primjerenost SFL teorije. [Peti isječak iz intervjua]

Drugim riječima, dok je Lee bila otvorena za novu teoriju i osjećala objašnjavajuću moć SFL-a kao teorije učenja jezika, također je nastojala razmišljati o znanju utemeljenom na SFL-u koje je dobivala. Povezujući svoja prijašnja iskustva učenja u učionicama čitanja sa svojim trenutnim znanjem (npr. sustavom vrednovanja) koje joj je dostupno, Lee je shvatila korist SFL-a za dobivanje kategorija koje pomažu pri objektivnijoj analizi tekstova umjesto oslanjanja na čitateljsku intuiciju ili neprincipijelnu analizu. To joj je pomoglo da vjeruje i stekne metalingvističko znanje utemeljeno na SFL-u. Nadalje, pažljivo povezujući tako utemeljeno znanje s teorijom učenja svoga materinskoga jezika, Lee je pronašla daljnje opravdanje za SFL perspektivu jezika kao sredstva stvaranja značenja.

\section{Poboljšanje Leeina novog metalingvističkog znanja nakon praktične primjene SFL-a}

Važno je naglasiti da se Leeino metalingvističko znanje utemeljeno na SFL-u kontinuirano poboljšavalo kroz njezina pozitivna iskustva prilikom primjene SFL-a za dekonstruiranje ili konstruiranje niza tekstova, kao što pokazuju sljedeći isječci iz intervjua:

Kada čitam znanstvene radove na engleskom, primjećujem kako su izvedene kohezivne veze... Također postoje tematski uzorci... i poseban odabir glagola radnje (kao procesa)... Od akademskih pisanih radova ne učim samo gramatička pravila... mogu primjenjivati SFL u analizi lingvističke razlike između engleskog $i$ kineskog putem analize utemeljene na SFL-u, poput manjka kohezivnih sredstava u kineskom, i moram izbjeći taj utjecaj pri upotrebi engleskoga... Uz pomoć SFL-a osjećam da, iako ima puno toga što treba naučiti, znam što i kako učiti kao studentica engleskoga jezika. [Šesti isječak iz intervjua] 
Mislila sam da su vijesti objektivne. Ali kada sam pokušala primijeniti sustav vrednovanja da dekodiram značenje... nalazim kako to nije istina... Smatram da je uvijek u njima sakriven stav izvjestitelja... Njihov se stav može primijetiti u izboru glagola ili priloga.... to sam mogla uočiti... mogla sam to samo intuitivno primjećivati... ali nisam jasno mogla artikulirati zašto je tomu bilo tako... To je bilo poražavajuće za studenta engleskoga jezika. Međutim, sada to mogu zbog moga SFL znanja. [Sedmi isječak iz intervjua]

Ova dva isječka ilustriraju kako je Leeino metalingvističko znanje dinamično povećano njezinim pozitivnim iskustvima učenja jezika. U praktičnoj primjeni SFL joj je pomogao pri analizi tekstova (npr. dubinsko razumijevanje novinskih izvještaja i lingvističkih manifestacija u znanstvenim radovima) na način koji nikada ne bi mogla postići svojim predznanjem; stvorene su prilike da se razvija kao napredna učenica jezika (ili studentica engleskoga jezika) i bude sposobna za analizu utemeljenu na dokazima u zastupanju argumenata. Najvažnije je da je zbog kategorija (npr. kohezivnih sredstava) Lee mogla pronaći međujezičnu razliku između engleskoga i kineskoga jezika, koja je mogla negativno utjecati na njezinu upotrebu engleskoga. To je nadalje ojačalo njezino samopouzdanje u internaliziranju metalingvističkog znanja utemeljenog na SFL-u.

\section{Vježbanje metalingvističkog jezičnog znanja s engleskom pismenosti: konkretni dokazi iz Leeinih dijaloških aktivnosti i pisanja}

U procesu stjecanja metalingvističkog znanja, Lee je svakako aktivno primjenjivala ta znanja u razvoju pismenosti. Tijekom razgovora s istraživačem o svome razumijevanju sadržaja tekstova različitih žanrova, Lee se uvijek koristila SFL kategorijama. To je pokazalo da se oslobodila ograničenja gramatičke dekonstrukcije ili konstrukcije tekstova i da se jasno pokazao njezin prijelaz od neizvornog učenika engleskoga kao stranoga jezika prema kulturološki i lingvistički osjetljivom učeniku.

\section{Leein eksplicitni govor o znanstvenim radovima i povezana analiza}

Reprezentativni ulomak razgovora koji slijedi pokazuje kako se studentica koristila SFL-om za razumijevanje znanstvenih tekstova. Originalni jezik bio je kineski. Ipak, zbog čitateljstva je isječak preveden na engleski:

Lee: Čitam znanstveni rad. Radi se o medijaciji Vygotskog. Dok ga čitam, razmišljam o SFL-u.

Istraživač: Kako to?

Lee: Vidite, u znanstvenim radovima isto imamo posebnu temu; također pišemo za našu publiku i organiziramo informacije. To je registar našeg znanstvenog pisanja.

Istraživač: $\mathrm{Da}$, molim nastavite.

Lee: U odnosu na tenor (sadržaj), interpersonalno značenje znanstvenih radova je vrlo oprezno. Glagoli kojima se izvještava, poput predložiti, implicirati, pokazati, 
imaju različite stupnjeve semantičke težine... učenici jezične djelatnosti pisanja moraju dobro poznavati... A citati su način podržavanja piščevih tvrdnji i postizanja uvjerljivosti informacija.

Istraživač: To je vrlo dobar osvrt na tvoje iskustvo i interpersonalno značenje u kontekstu. Još nešto?

Lee: Da. Prilikom uvođenja socio-kulturološke teorije, autor se koristio mnogim riječima vezanim uz temu, poput „ljudski”, „društvo” $\mathrm{i}$ „kultura” ili takozvani sudionici... to sadržaj za čitatelje čini jasnim i objektivnim... procesni glagoli poput "regulirati” $i$ „osnažiti” su sve glagoli radnje... Ti glagoli jasno pokazuju kako društvo utječe na ljudsku kogniciju.

Istraživač: Odlično! Zaista profesionalan osvrt na idejno značenje u znanstvenom pisanju! Još nešto?

Lee: Da razmislim. O, česta je upotreba kohezivnih sredstava... poput medijator i posredovati, što može sačinjavati poveznice unutar odlomka. Ipak, to je pisani jezik i čitatelji očekuju da je zaista tečan.

Istraživač: Odlično!

Ovaj razgovor između Lee i istraživača dogodio se tijekom drugog semestra jednogodišnjeg projekta. U to vrijeme Lee je već bila upoznata sa SFL-om. Prilikom razgovora o znanstvenom pisanju s istraživačem, Lee je vješto navela primjere svog znanja utemeljenog na SFL-u pri analizi mita koji se povezuje s pisanjem znanstvenih tekstova, navigirajući odnos između znanstvenog registra, značenja i lingvističkih obilježja koji se očekuju od dominantnih engleskih zajednica. Na primjer, Lee je objasnila važnost odabira imenica i glagola pri stvaranju idejnog značenja kao dimenziju sadržaja znanstvenih radova, posredstvom izraza proces i sudionik. Ne samo da se koristila tim izrazima već je također objasnila i razloge spomenutih lingvističkih odabira komentirajući zahtjeve konteksta prema situacijskoj varijabli (polju) u znanstvenom pisanju. Slično tomu, naglašavajući važnost publike u procesu pisanja, Lee je pokazala svoju vještinu pri razumijevanju međuodnosa između konteksta situacijske varijable (tenor/sadržaj) i interpersonalnog značenja u znanstvenom pisanju. Upoznata sa SFL-om, u smislu važnosti piščeva povezivanja s čitateljima, Lee se koristila izrazom „angažman” kada je govorila o važnosti citata i o tome kako snaga dokaza također mora biti primjereno označena za čitatelje putem glagola izvještavanja (pokazati vs. implicirati). Njezino metalingvističko poznavanje registarske varijable modusa (kanala komunikacije) i njezina odnosa s lingvističkim osobinama također je označeno u razgovoru s istraživačem. Drugim riječima, Lee se koristila izrazom kohezija kada je govorila o leksičkoj povezanosti između glagola (posredovati) i imenice (posredovanje). Također je objasnila kauzalni odnos između kohezije i modusa komunikacije s prvospomenutim koje je uzrokovano potonjim. Zaključno, sve dok nije postala vješta u SFL-u, Lee je prelazila od razumijevanja SFL znanja do analize sadržaja pismenosti na engleskom jeziku i opravdavala svoju analizu, što ne bi postigla samo svojim predznanjem puke strukturne točnosti engleskoga jezika. 


\section{Leeino poboljšanje vještina oblikovanja teksta primjenom SFL znanja}

Tijekom akademske godine Lee je postupno primijenila znanje utemeljeno na SFL-u u svojoj jezičnoj praksi (npr. čitanje, pisanje). Ipak, put prijelaza od održavanja rečenične preciznosti do primjerenosti diskursa činio se teškim procesom (bilješke s terena). $\mathrm{Na}$ primjer, u prva dva pisana zadatka tijekom prvog mjeseca prvoga semestra, Lee nije još bila upoznata sa SFL-om i njezino pisanje bilo je slično onomu ostalih učenika ESJ u kojemu je naglasak bio na točnosti pojedinih rečenica. Štoviše, cijelo je djelo bilo neprimjereno u smislu idejnog značenja, interpersonalnog značenja i kohezivnih sredstava (Fu i Matoush, 2012; vidi i tablicu 1 ispod). Ipak, tijekom njezina postupnog upoznavanja sa SFL-om, kao i zbog istraživačevih usmenih i pisanih povratnih informacija, postala je konzistentna u pisanju svojih nacrta, sama revidirajući svoje pisanje i predajući tekstove koji imaju primjereno značenje i dovoljno dobre lingvističke osobine koje podržavaju zajednice akademske pismenosti (vidi tablicu 1).

Tablica 1

Promjene Leeina metalingvističkog znanja i pismenosti

\begin{tabular}{|c|c|c|}
\hline & $\begin{array}{l}\text { Pisanje na početku akademske } \\
\text { godine }\end{array}$ & $\begin{array}{l}\text { Pisanje nakon poduke utemeljene na } \\
\text { SFL-u }\end{array}$ \\
\hline Idejno značenje & $\begin{array}{l}\text { Bez pridavanja pažnje logičkim } \\
\text { vezama; } \\
\text { Bez pažnje za leksičke odabire ili } \\
\text { odabire glagola vezanih uz temu } \\
\text { (npr. prečesta upotreba mi kao } \\
\text { sudionika) }\end{array}$ & $\begin{array}{l}\text { Kontrola glagola koji označavaju } \\
\text { proces primjenom glagola radnje; } \\
\text { Kontrola sudionika primjenom } \\
\text { leksičkih izbora vezanih uz temu (npr. } \\
\text { rjeđa upotreba zamjenice mi kao } \\
\text { subjekta) }\end{array}$ \\
\hline $\begin{array}{l}\text { Interpersonalno } \\
\text { značenje }\end{array}$ & $\begin{array}{l}\text { Bez poznavanja citiranja; } \\
\text { Bez poznavanja glagola } \\
\text { stupnjevanja (npr. glagoli su ili biti } \\
\text { ili ne biti; malo je glagola između, } \\
\text { poput činiti se, moći) }\end{array}$ & $\begin{array}{l}\text { Primjeren angažman posredstvom } \\
\text { citata koji podupiru njezine tvrdnje } \\
\text { (npr. iskorištavanje informacija iz vijesti } \\
\text { i istraživačkih radova); } \\
\text { Kontrola semantičkog segmenta } \\
\text { primjenom raznolikih glagola ili } \\
\text { modalnih glagola poput reći, pokazati, } \\
\text { implicirati, činiti se i moći }\end{array}$ \\
\hline $\begin{array}{l}\text { Tekstualno } \\
\text { značenje }\end{array}$ & $\begin{array}{l}\text { Gotovo potpun izostanak svijesti } \\
\text { o progresiji tema -rema; } \\
\text { Ograničene kohezivne veze, } \\
\text { posebno leksičke (npr. labave veze } \\
\text { između rečenica) }\end{array}$ & $\begin{array}{l}\text { Upotreba stalne teme (npr. } \\
\text { ponavljanje iste teme) kako bi se } \\
\text { postigla kohezija; } \\
\text { Dobro upotreba kohezivnih veza (npr. } \\
\text { veznici ili leksičke veze) u stvaranju } \\
\text { koherentnih tekstova }\end{array}$ \\
\hline
\end{tabular}

Kao što prikazuje tablica 1, u početku je Lee bila ograničena svojim prethodnim metalingvističkim znanjem koje se fokusiralo na strukturalnu točnost; njezino pisanje pokazivalo je otklon od znanstvenog registra I lingvističkih manifestacija. $\mathrm{Na}$ lingvističkoj razini nije imala jasnu svijest o razlici između govorenog i pisanog engleskog jezika (npr. nedostatak jake veze između rečenica). Iskustva materinskoga jezika studentice također su mogla utjecati na njezino pisanje na engleskom. Naime, 
kineski je usredotočen na pisca, a od čitatelja se očekuje da dekodira značenje; također ograničeno se koristi kohezivnim sredstvima (Lian, 1993). Na interpersonalnoj razini Lee također nije posjedovala vještine učinkovitog ni primjerenog prenošenja informacije čitateljima. Njezino pisanje izražavalo je ili pozitivno (npr. je) ili negativno značenje (npr. nije), bez upotrebe glagola koji označavaju razine značenja između je i nije (npr. činiti se, moći). Njezino idejno značenje bilo je dobro iako logičke veze između rečenica povremeno nisu bile izrečene, što također može biti zbog preferencije za implicitnim logičkim vezama u njezinu materinskom jeziku (Lian, 1993). Ipak, tijekom akademske godine Lee je primijenila SFL znanje u svom pisanju. Na idejnoj razini njezino pisanje je poslije pokazalo jasne logičke veze. Na interpersonalnoj razini također se često koristila glagolima stupnjevanja (npr. činiti se) izražavajući svoju tvrdnju kada dokazi nisu bili dovoljno jaki. Na tekstualnoj razini koristila se leksičkom i gramatičkom kohezijom kako bi povezala pisanje. Drugim riječima, Lee je očito bila sposobna slijediti svoje novo stečeno metalingvističko znanje postupno ga primjenjujući u svom pisanju, što joj je pomoglo prilikom prevladavanja ograničenja svoga prethodnog obrazovanja iz engleskoga jezika, kao i iskustva učenja materinskoga jezika.

\section{Rasprava}

Ova studija istraživala je kako SFL utječe na metalingvističko znanje i pismenost učenice engleskoga kao stranoga jezika na tercijarnoj razini. Jedan od rezultata jednogodišnje studije slučaja bio je da je Lee bila otvorena za metalingvističku teoriju utemeljenu na SFL-u i da je bila motivirana i strastvena učenica jezika zbog svog novostečenog znanja jezika. Te se spoznaje podudaraju s onima u kontekstu EDJ u kojimu je utvrđena pozitivna veza između učeničkog metalingvističkog znanja utemeljenog na SFL-u i primjene (usp. Chen i Myhill, 2016; Gebhard i sur., 2014; Humphrey i Macnaught, 2016). Rezultati se također naslanjaju na oskudnu literaturu o primjeni SFL-a u razvijanju učeničkog metalingvističkog znanja u tercijarnom kontekstu učenja engleskoga kao stranoga jezika (usp. Humphrey i sur., 2016). Nadalje, za razliku od prijašnjih istraživanja u kojima su učenici pružali otpor prema novim znanjima koja su vrlo različita od njihovih prijašnjih iskustava učenja (npr. Margolis, 2001; Zembylas, 2008), ovo istraživanje pokazuje važnost održavanja zdravih principa koji uključuju učeničku trenutnu jezičnu razinu i sposobnosti za napredovanje. Na taj način učenici nisu imali mnogo poteškoća pri prijelazu na novu perspektivu jezika (usp. Gebhard, 2010; Macken-Horarik, 2012). Najvažnije je da je u području jezičnog obrazovanja odnos između osobe, profesionalnog identiteta i učeničke motivacije bio naglašavan, iako su u empirijskim studijama predstavljene ograničene strategije poučavanja (usp. Tran, 2007; Ushioda, 2011). U ovom je istraživanju metalingvističko znanje utemeljeno na SFL-u pomoglo učenici da stekne pozitivno iskustvo u usavršavanju pismenosti u engleskom jeziku i motiviralo ju da dalje ulaže u sebe i testira vlastite granice u razumijevanju složenosti SFL-a te da nastavlja učiti o engleskome jeziku kao studentica engleskoga jezika, radije nego da se samo bazira na gramatiku. Drugim riječima, istraživanje također 
pruža jedinstven lingvistički pristup u razvoju trijadnog odnosa između identiteta učenice engleskoga jezika, motivacije i samoposredovanja.

Osim toga, još jedan rezultat istraživanja pokazuje da SFL metalingvističko znanje, koje premošćuje rečeničnu točnost, lingvističke izbore i stvaranje značenja u kontekstu, širi učeničko predznanje i olakšava njezinu uporabu jezika. Na primjer, novo joj je znanje ponudilo dostupan alat za poboljšanje pismenosti u engleskom jeziku. Zbog osvježenog znanja Lee je mogla posegnuti za tvrdnjama utemeljenim na dokazima kao učenica engleskoga kao stranoga jezika. Drugim riječima, suprotno uvriježenoj tvrdnji da su učenici ESJ pasivni primatelji informacija, Lee je izašla izvan ograda kulture svoga materinskoga jezika u kojem se tvrdnje nepodržane dokazima često javljaju u svakodnevnoj komunikaciji (usp. Lian, 1993; Zhang, 1999). To odražava novije spoznaje prema kojima učenici ESJ postaju željni učenja jezika u kojem će kritički razmišljati (usp. Stapleton, 2002). Nadalje, oslanjajući se na svoje SFL znanje, Lee se pokazala kao kulturološki i lingvistički prilagođen član međunarodno priznatih zajednica engleskoga jezika. Točnije, Leeino poboljšanje vještina utemeljeno na praksi nadalje je pokazalo moć SFL-a u obogaćivanju pismenosti učenika jezika i osiguranju sredstva koje može pomoći edukatorima koji se bore za poboljšanje lingvističkih vještina učenika ESJ u skladu s očekivanjima zajednica engleskoga jezika (Fu i Matoush, 2012; Zhang, 2017). Najvažnije, Leeino osvježeno znanje i pozitivna iskustva osnažila su njezino samopouzdanje, što je poslužilo kao katalizator za SFL metalingvističko znanje. Drugim riječima, Leein slučaj također podupire naše viđenje iskustva utemeljenog na praksi kao pokretača učeničkog poboljšanog razumijevanja teorije i motivatora za nastavak njegove primjene u budućem učenju (usp. Negretti, 2012).

Implikacije ovoga istraživanja uključuju tri dimenzije. Prvo, kako važni testovi u mnogim kontekstima ESJ favoriziraju lingvističku točnost, učenici bi mogli pogrešno pomisliti da je njihova uloga samo rafinirati svoje znanje rečenične strukture i postići dobre rezultate na testovima. Zbog učeničkih dugotrajnih interesa za engleske zajednice, posebno zbog naprednih učenika jezika na tercijarnoj razini koji već imaju dovoljno dobro znanje gramatike, imperativ za edukatore je da nadopune učeničko metalingvističko znanje, na primjer uz pomoć SFL načela. Krajnja je svrha diversifikacije metalingvističkog znanja učenika jezika ispunjavanje komunikacijskih očekivanja u zajednicama izvornih govornika engleskoga jezika, poput sposobnosti konstruiranja smislenog diskursa u ulozi pisca i dekodiranja skrivenih značenja u tekstovima putem analize. Drugo, istraživanje također sugerira da učenici trebaju izaći iz svojih sigurnih zona i rekonstruirati vlastito metalingvističko znanje. Međutim, rekonstruiranje metalingvističkog znanja nije bez prepreka (Chen i Myhill, 2016; Gebhard, 2010). Učenici, posebno napredni učenici jezika, kada ih se vodi tako da vide koristi SFL-a, moraju biti motivirani da pred sebe kontinuirano postavljaju nove izazove. Ipak, kako je ustvrdio Ushioda (2010),,,Motivacija je oblikovana poželjnom slikom o sebi u socijalnom, osobnom ili profesionalnom kontekstu upotrebe drugoga jezika" (str. 30). Drugim riječima, promjena učeničkih metalingvističkih znanja ovisi o njihovoj sposobnosti da shvate važnost postizanja 
jezičnog identiteta koji prepoznaju dominantno engleske zajednice. Treće, unatoč naglasku mnogih važnih testova ESJ na jezičnoj točnosti, nastavnici jezika trebali bi stvoriti okolinu u kojoj će učenici imati izravno iskustvo s novim metalingvističkim znanjem (npr. SFL), kroz koje edukatori mogu promatrati doprinosi li novo znanje uspjehu učenika ESJ u znanstvenoj pismenosti na engleskom jeziku.

\section{Zaključci}

Ovo istraživanje temelji se na argumentu da bi, umjesto da mjere svoj uspjeh na osnovi dekontekstualizirane gramatike, učenici ESJ trebali usvojiti odgovarajuće metalingvističko znanje te biti spremni za izazove članstva u autentičnim zajednicama engleskoga jezika. Na temelju jednogodišnjeg projekta kojim su ispitana iskustva učenice ESJ s eksplicitnom podukom o perspektivi jezika utemeljenom na SFL-u u smislu stvaranja značenja u kontekstu, mogu se izvesti dva važna zaključka koja potvrđuju nedovoljan broj istraživanja o preoblikovanju metalingvističkog znanja i primjene jezika učenika ESJ, a s ciljem prilagođavanja dominantnim engleskim zajednicama. Prvo, istraživanje pokazuje kako se studentica koja je već dobro poznavala gramatička pravila na rečeničnoj razini entuzijastično uključila u stjecanje metalingvističkog znanja utemeljenog na SFL-u. Taj proces bio je kataliziran širokim rasponom unutarnjih i vanjskih čimbenika poput: želje učenice za izgradnjom vlastitog profesionalnog identiteta, samoposredovanja u razmišljanju o prijašnjim iskustvima učenja engleskoga jezika i svijesti učenice o moći metalingvističkog znanja utemeljenog na SFL-u, što joj je proširilo perspektivu. Drugo, istraživanje pokazuje da je, kada je bila vođena perspektivom jezičnih osobina konteksta i stvaranja značenja u tekstovima utemeljenom na SFL-u, studentica mogla premašiti svoje predznanje usmjereno na učenje gramatičkih pravila ili akumuliranje novih riječi. Drugim riječima, transformirala se u lingvistički i kulturološki osjetljivog učenika jezika u smislu korištenja SFL-a pri razgovoru o tekstovima, prilikom argumentiranja utemeljenog na dokazima, ili se koristila SFL-om kako bi pokazala pismenost u engleskom jeziku kakvu očekuju autentične zajednice engleskoga jezika.

Buduća istraživanja mogla bi se temeljiti na akcijskim istraživanjima utemeljenim na SFL-u među učiteljima u službi i budućim učiteljima koji su obrazovani za primjenu odgovarajućih metoda u poduci jezika i pomoći učenicima kombinirajući tradicionalna znanja o strukturalnoj točnosti s dovoljno dobrim znanjem SFL-a, sa svrhom zadovoljavanja zahtjeva autentičnih engleskih jezičnih zajednica (MackenHorarik, 2012).

\section{Zahvala}

Projekt je financiran sredstvima MO (Ministarstva obrazovanja u Kini) u sklopu ključnog projekta humanističkih i društvenih znanosti (16JJD740002). 